\title{
Utilization of dried microbial cells grown on methanol in a semi-purified diet for growing pigs
}

\author{
By J. P. F. D'MELLO, D. G. PEERS ANd C. T. WHITTEMORE \\ School of Agriculture, University of Edinburgh, \\ West Mains Road, Edinburgh $\mathrm{EH}_{9} 3 \mathcal{F G}$
}

(Received 5 November I975-Accepted 30 April 1976)

\begin{abstract}
1. Twenty-four pigs (mean body-weight $44 \mathrm{~kg}$ ) were used to determine the digestibilities of energy, nitrogen and amino acids in dried microbial cells (DMC) grown on methanol and in white fish meal (WFM). $N$ utilization and the excretion of various nitrogenous compounds were also studied.

2. Semi-purified diets containing DMC, WFM or no protein source were offered at the rate of $\mathrm{I} \mathrm{kg}$ fresh food/d. Daily $\mathrm{N}$ intakes were $26.5,24.7$ and $0.65 \mathrm{~g}$ respectively.

3. Mean metabolic faecal $N$ determined with the protein-free diet was $I \cdot I \mathrm{I} / \mathrm{d}(\mathrm{I} \cdot 26 \mathrm{~g} / \mathrm{kg}$ dry matter (DM) eaten) for the two experiments. The corresponding endogenous urinary $\mathrm{N}$ value was $2.91 \mathrm{~g} / \mathrm{d}$.

4. Daily urinary $N$ output of pigs given the diet with WFM was significantly greater than that of pigs given the diet with $\mathrm{DMC}$, with the result that $\mathrm{N}$ retention, net protein utilization and biological value were higher for pigs given DMC.

5. Apparent and true digestibility of amino acids were higher for the diet with DMC than for the diet with WFM.

6. $\mathrm{N}$ excretion in the form of ammonia, urea, uric acid and allantoin accounted for $8 \mathrm{I}$, 9I and $99 \%$ of the total $\mathrm{N}$ excreted by the groups given the protein-free diet, DMC and WFM respectively. Pigs given DMC excreted greater quantities of allantoin- $N$ and less urea-N than pigs given WFM.
\end{abstract}

In a recent study with pigs (Braude, Mitchell \& Rhodes, r975) dried microbial cells (DMC) grown on methanol replaced white fish meal (WFM) on the basis of its content of non-nucleic acid-nitrogen. There were no significant differences in daily gain, efficiency of food conversion or $\mathrm{N}$ retention between pigs given WFM diets at 'standard' and 'marginal' protein levels and those given diets with DMC. Oslage \& Schulz (1974), however, reported lower digestibilities of organic matter and of crude protein $(\mathrm{N} \times 6 \cdot 25)$ for bacterial products as compared with $n$-paraffingrown yeast.

In the present study, semi-purified diets were used to determine the digestibilities of energy, $\mathrm{N}$ and amino acids in methanol-grown DMC and in WFM. In addition $\mathrm{N}$ utilization and the excretion of various nitrogenous compounds in the urine were also studied.

\section{EXPERIMENTAL}

\section{Animals and management}

Twenty-four Large White $\times$ Landrace (LWL) barrows of $43.5 \pm 0.39$ (sE) kg live weight were used, two groups of twelve animals in replicate balance experiments. The pigs were accommodated in pens for a preliminary period of $3 \mathrm{~d}$ and received a mixture of equal quantities of the diets containing DMC and WFM (see Table 2). 
Table I. Amino acid and nitrogen contents ( $\mathrm{g} / \mathrm{kg}$ dry matter) of methanol-grown, dried microbial cells (DMC) and white fish meal (WFM)

$\begin{array}{lrr}\text { Amino acid } & \text { DMC } & \text { WFM } \\ \text { Aspartic acid } & 74 \cdot 9 & 54 \cdot 3 \\ \text { Threonine } & 39 \cdot 8 & 29 \cdot 8 \\ \text { Serine } & 25 \cdot 8 & 37 \cdot 2 \\ \text { Glutamic acid } & 103 \cdot 5 & 91 \cdot 6 \\ \text { Glycine } & 57 \cdot 1 & 63 \cdot 9 \\ \text { Alanine } & 59 \cdot 9 & 40 \cdot 5 \\ \text { Valine } & 49 \cdot 0 & 39 \cdot 5 \\ \text { Cystine } & 6 \cdot 3 & 10 \cdot 0 \\ \text { Methionine } & 18 \cdot 4 & 17 \cdot 0 \\ \text { Isoleucine } & 33 \cdot 4 & 28 \cdot 8 \\ \text { Leucine } & 55 \cdot 7 & 47 \cdot 8 \\ \text { Tyrosine } & 34 \cdot 7 & 24 \cdot 7 \\ \text { Phenylalanine } & 42 \cdot 3 & 30 \cdot 1 \\ \text { Lysine } & 45 \cdot 8 & 36 \cdot 4 \\ \text { Histidine } & 15 \cdot 4 & 11 \cdot 9 \\ \text { Arginine } & 37 \cdot 7 & 42 \cdot 4 \\ \text { Tryptophan } & 7 \cdot 7 & 7 \cdot 0 \\ \text { N } & & \\ \text { Total N } & 129 \cdot 9 & 110 \cdot 0 \\ \text { Nucleic acid-N } & 24 \cdot 2 & 0 \cdot 6 \\ \text { N recovered as amino acids } & 96 \cdot 3 & 86 \cdot 2\end{array}$

The pigs were then transferred to 'balance' cages and allocated at random to the three dietary treatments. A further period of $3 \mathrm{~d}$ on the experimental diets preceded the separate bulked collection of faeces and urine over a period of Io d. During the experiments faeces and urine were maintained at $\mathrm{pH}_{3}$ by additions of dilute sulphuric acid.

\section{Diets}

The batches of DMC (Pruteen; Imperial Chemical Industries Ltd, Billingham, Cleveland) and WFM were analysed for amino acids by automated ion-exchange chromatography (Table $\mathrm{I}$ ). The composition of the three diets used is given in Table 2. A protein-free (PF) diet based on maize starch, sucrose and glucose was used to estimate endogenous components in faeces and urine. In the other two diets methanol-grown DMC and WFM were added at the expense of starch, thus constituting the only supply of $\mathrm{N}$ to these diets. The determined analytical composition of the diets is given in Table 3. Adequate quantities of minerals, vitamins and antioxidant were ensured by the inclusion of special mixtures. The composition of the mixture used in the PF and DMC diets is given in Table 2. The mixture added to the WFM diet had a similar composition to that given in Table 2 except that the calcium and phosphorus components were omitted to take account of the contribution of WFM.

All pigs were fed once daily and received I $\mathrm{kg}$ fresh food mixed with $2 \mathrm{~kg}$ water. Mean dry matter (DM) intakes of pigs on the PF, DMC and WFM diets were $886.7,894.7$ and $889.7 \mathrm{~g} / \mathrm{d}$ which corresponded to $\mathrm{N}$ intakes of $0.65,26.52$ and $24.70 \mathrm{~g} / \mathrm{d}$ respectively, and gross energy $(\mathrm{GE})$ intakes of $14 \cdot 52,15.76$ and $16 \cdot 27 \mathrm{MJ} / \mathrm{d}$ respectively. 
Table 2. Composition $(\mathrm{g} / \mathrm{kg})$ of the protein-free diet $(P F)$, and of the diets containing methanol-grown, dried microbial cells (DMC) and white fish meal (WFM) fed to growing pigs

\begin{tabular}{lccc} 
& \multicolumn{3}{c}{ Diet } \\
\cline { 2 - 3 } & $\overbrace{\text { PF }}$ & DMC & WFM \\
Ingredient & 750 & 540 & 555 \\
Maize starch & 30 & 30 & 30 \\
Cellulose & 50 & 50 & 50 \\
Sucrose & 50 & 50 & 50 \\
Glucose & - & 210 & - \\
Methanol-grown DMC & - & - & 240 \\
WFM & 70 & 70 & $25 \dagger$ \\
Mineral and vitamin mixture* & 50 & 50 & 50 \\
Maize oil & &
\end{tabular}

* Supplied (/kg diet): calcium $11.8 \mathrm{~g}$, phosphorus $8.0 \mathrm{~g}$, sodium chloride $5.0 \mathrm{~g}$, potassium $5.0 \mathrm{~g}$, magnesium $400 \mathrm{mg}$, iron $60 \mathrm{mg}$, zinc $60 \mathrm{mg}$, manganese $20 \mathrm{mg}$, copper $10 \mathrm{mg}$, cobalt $0.5 \mathrm{mg}$, iodine $0.8 \mathrm{mg}$, thiamin $4.0 \mathrm{mg}$, riboflavin $5.0 \mathrm{mg}$, nicotinamide $30.0 \mathrm{mg}$, pantothenic acid $10.0 \mathrm{mg}$, pyridoxine $2.5 \mathrm{mg}$, pteroylmonoglutamic acid $2.0 \mathrm{mg}$, choline $1000 \mathrm{mg}$, cyanocobalamin $20.0 \mu \mathrm{g}$, retinol 901 $\mu \mathrm{g}$, biotin $200 \mu \mathrm{g}$, cholecalciferol $25.0 \mu \mathrm{g}, \mathrm{D}-\alpha$-tocopherol ro.0 $\mathrm{mg}$, menaphthone I $20 \mu \mathrm{g}$, butylated hydroxytoluene $0.125 \mathrm{~g}$.

$\uparrow \mathrm{Ca}$ and $\mathrm{P}$ components of mixture omitted.

Table 3. Chemical composition of the protein-free diet $(P F)$ and of the diets containing methanol-grown, dried microbial cells (DMC) and white fish meal (WFM) fed to growing pigs

(For amino acid content determined values are given, with values calculated from values given in Table $I$ in parentheses)

\begin{tabular}{|c|c|c|c|}
\hline & & Diet* & \\
\hline & PF & DMC & WFM \\
\hline $\begin{array}{l}\text { Dry matter (DM) (g/kg) } \\
\text { Gross energy (MJ } / \mathrm{kg} \mathrm{DM}) \\
\text { Nitrogen }(\mathrm{g} / \mathrm{kg} \mathrm{DM})\end{array}$ & $\begin{array}{l}887 \cdot 0 \\
16 \cdot 4 \\
0 \cdot 74\end{array}$ & $\begin{array}{r}894 \cdot 0 \\
17 \cdot 6 \\
29 \cdot 7\end{array}$ & $\begin{array}{r}890 \cdot 0 \\
18 \cdot 3 \\
27 \cdot 8\end{array}$ \\
\hline Mineral content (g/kg DM) & & & \\
\hline Phosphorus & $9 \cdot 3$ & 13.9 & $6 \cdot 8$ \\
\hline Calcium & 14.8 & 15.2 & $12 \cdot 3$ \\
\hline Sodium & $2 \cdot 2$ & $4 \cdot 6$ & $3 \cdot 2$ \\
\hline Potassium & $7 \cdot 6$ & $8 \cdot 2$ & $9 \cdot 6$ \\
\hline Magnesium & 0.64 & I.19 & 0.91 \\
\hline Amino acid content $(\mathrm{g} / \mathrm{kg}$ DM & & & \\
\hline Threonine & - & $I I \cdot 7(8 \cdot 4)$ & $8 \cdot 3(7 \cdot 2)$ \\
\hline Glycine & - & $14 \cdot 0(12 \cdot 0)$ & $17 \cdot 4(15 \cdot 3)$ \\
\hline Valine & - & $12 \cdot 3(10.3)$ & $9 \cdot 4(9 \cdot 5)$ \\
\hline Cystine & - & $1 \cdot 5(1 \cdot 3)$ & $2.7(2.4)$ \\
\hline Methionine & - & $4 \cdot 7(3 \cdot 9)$ & $3 \cdot 7(4 \cdot 1)$ \\
\hline Isoleucine & - & $8.7(7 \circ 0)$ & $6.4(6.9)$ \\
\hline Leucine & - & $13.6(11.7)$ & $10.4(1 \times 5)$ \\
\hline Tyrosine & - & $6 \cdot 9(7 \cdot 3)$ & $5 \cdot 2(5 \cdot 9)$ \\
\hline Phenylalanine & - & $7.9(8.9)$ & $6 \cdot 4(7 \cdot 2)$ \\
\hline Lysine & - & $\mathrm{II} \cdot 5(9.6)$ & $7.9(8 \cdot 7)$ \\
\hline Histidine & - & $4 \cdot 0(3 \cdot 2)$ & $2.5(2.9)$ \\
\hline Arginine & - & $9 \cdot 1(7 \cdot 9)$ & $9 \cdot 4(10 \cdot 2)$ \\
\hline
\end{tabular}

* For details, see Tables 1 and 2. 


\section{Experimental techniques}

Amino acid analysis of ingredients, diets and freeze-dried samples of faeces was carried out as follows: between 150 and $300 \mathrm{mg}$ of material (depending upon $\mathrm{N}$ content) were hydrolysed under $\mathrm{N}_{2}$ in $300 \mathrm{ml} 6 \mathrm{M}-\mathrm{HCl}$ at II $5^{\circ}$ for $22 \mathrm{~h}$. Each hydrolysate was diluted with deionized water to $500 \mathrm{ml}$ in a volumetric flask and filtered through a sintered-glass funnel. A portion $(5 \mathrm{ml})$ of the filtrate was then evaporated to dryness using a rotary evaporator and the residue taken up in $2 \mathrm{ml}$ of a solution of $100 \mathrm{~g}$ sucrose/ $/ \mathrm{O} \cdot \mathrm{I} \mathrm{M}-\mathrm{HCl}$ and analysed for amino acids using an amino acid analyser (Model NCr; Technicon Instruments Co. Ltd, Basingstoke, Hants). Norleucine $(0.25 \mu \mathrm{mol} / \mathrm{ml})$ was used as an internal standard.

Tryptophan was determined in alkaline hydrolysates by the method of Inglis \& Leaver (1964).

$\mathrm{N}$ was determined by the Kjeldahl technique and GE using an adiabatic bomb calorimeter (A. Gallenkamp \& Co. Ltd, Christopher Street, London).

Automated methods of analysis were used to determine urine concentrations of urea-N (Marsh, Fingerhut \& Miller, 1965), allantoin-N (Pentz, 1970) and uric acid-N (Crowley, 1964). Ammonia- $\mathrm{N}$ in urine was determined using an ammonia probe (Model 8002-2; Electronic Instruments Ltd, Chertsey, Surrey).

The nucleic acid contents of methanol-grown DMC and of WFM were determined by measuring extinction at $260 \mathrm{~nm}$ after perchloric acid extraction to precipitate protein.

\section{RESULTS}

The results of the balance experiments are presented in Tables $4^{-6}$. The values for digestibility coefficient, $\mathrm{N}$ retention and biological value (BV) obtained in the replicate experiments have been pooled. Mean metabolic faecal $\mathrm{N}$ in the replicate experiments with the $P F$ diet were $\mathrm{I} \cdot 06$ and $\mathrm{I} \cdot \mathrm{I} 6 \mathrm{~g} / \mathrm{d}(\mathrm{I} \cdot 20$ and $\mathrm{I} \cdot 3 \mathrm{I} \mathrm{g} / \mathrm{kg}$ DM consumed). Corresponding mean endogenous urinary $\mathrm{N}$ values (PF diet) were 3.20 and $2.62 \mathrm{~g} / \mathrm{d}$. No differences were found in the digestibility of $\mathrm{DM}, \mathrm{GE}$ or $\mathrm{N}$ (Table 4 ), but digestible and metabolizable energy values of the diet containing WFM were higher $(P<0.001)$ than those of the diet containing DMC. Since daily urinary $N$ output of pigs given the WFM diet was higher $(P<0.05)$ than that of pigs given DMC, N retention was correspondingly lower, as were net protein utilization and $\mathrm{BV}(P<0.0 \mathrm{I})$.

Estimates of digestibility of individual amino acids in methanol-grown DMC and in WFM were obtained from the second replicate experiment only. Endogenous outputs of amino acids in the faeces are given in Table 5. These values were used to calculate the true digestibilities of amino acids in the diets containing WFM and DMC (Table 6). The apparent and true digestibilities of amino acids for the diet with DMC were higher than those for the diet with WFM for fifteen of the sixteen amino acids studied (the exception being glycine). These differences were statistically significant for seven amino acids for apparent digestibility and three amino acids for true digestibility.

The nitrogenous compounds in the urine of pigs given the three diets is given 
Table 4. Digestibilities and nitrogen balance results for the protein-free diet $(P F)$ and for the diets containing methanol-grown, dried microbial cells $(D M C)$ and white fish meal (WFM) fed to growing pigs

(Pooled values for replicate experiments using twelve animals/replicate; eight animals/diet)

\begin{tabular}{|c|c|c|c|c|c|}
\hline \multirow[b]{3}{*}{ Intake (/d) } & \multicolumn{3}{|c|}{ Diet } & \multirow{2}{*}{$\begin{array}{c}\text { SE of } \\
\text { treatment } \\
\text { means }\end{array}$} & \multirow[t]{2}{*}{$\begin{array}{c}\text { Statistical } \\
\text { significance } \\
\text { of } \\
\text { difference } \\
\text { between } \\
\text { diets with } \\
\text { DMC } \\
\text { and WFM }\end{array}$} \\
\hline & PF & DMC & WFM & & \\
\hline & & & & & \\
\hline Dry matter (DM) (g) & $886 \cdot 7$ & $894 \cdot 2$ & $889 \cdot 7$ & - & \\
\hline Gross energy (GE) (MJ) & 14.52 & $15 \cdot 76$ & $16 \cdot 27$ & $一$ & \\
\hline$N(g)$ & 0.65 & $26 \cdot 52$ & 2470 & - & \\
\hline \multicolumn{6}{|l|}{ Digestibility } \\
\hline DM (apparent) & 0.929 & 0.910 & 0.924 & 0.0074 & NS \\
\hline GE (apparent) & 0.948 & 0.952 & 0.951 & 0.0044 & NS \\
\hline$N$ (apparent) & - & 0.937 & 0.932 & 0.0060 & NS \\
\hline $\mathbf{N}$ (true) & 一 & 0.979 & 0.977 & 0.0060 & NS \\
\hline \multicolumn{6}{|l|}{ Energy content } \\
\hline $\begin{array}{l}\text { Digestibility energy (DE) } \\
(\mathrm{MJ} / \mathrm{kg} \mathrm{DM})\end{array}$ & $15 \cdot 5$ & $16 \cdot 8$ & $17 \cdot 4$ & 0.08 & *** \\
\hline $\begin{array}{l}\text { Metabolizable energy } \\
\text { (ME) (MJ/kg DM) }\end{array}$ & $15 \cdot 3$ & $16 \cdot 3$ & $16 \cdot 8$ & 0.09 & $* * *$ \\
\hline ME:DE & 0.986 & 0.970 & 0.965 & 0.0012 & $*$ \\
\hline \multicolumn{6}{|l|}{$\mathrm{N}$ balance } \\
\hline Faecal $N(g / d)$ & $\mathbf{I} \cdot \mathbf{I} I$ & $1 \cdot 67$ & $1 \cdot 68$ & 0.141 & NS \\
\hline Urinary $N(g / d)$ & 2.91 & $11 \cdot 17$ & $12 \cdot 85$ & 0.486 & $*$ \\
\hline $\begin{array}{l}\mathrm{N} \text { retention }(\mathrm{g} / \mathrm{d}) \\
\mathrm{N} \text { retention } \div \mathrm{N} \text { intake }\end{array}$ & $-\underline{-3 \cdot 4}$ & $\begin{array}{l}13.7 \\
0.516\end{array}$ & $\begin{array}{l}10.2 \\
0.416\end{array}$ & $\begin{array}{l}0.55 \\
0.0214\end{array}$ & *** \\
\hline $\begin{array}{l}\mathrm{N} \text { retention } \div \text { digested } \mathrm{N} \\
\text { intake }\end{array}$ & - & 0.549 & 0.441 & 0.0200 & $* *$ \\
\hline Net protein utilization & 一 & 0.667 & 0.575 & 0.0210 & $* *$ \\
\hline Biological value (true) & - & 0.680 & 0.588 & 0.0186 & $* *$ \\
\hline
\end{tabular}

NS, not significant.

* $P<0.05, \quad * * P<0.01, \quad * * * P<0.001$.

+ For details, see Tables $\mathbf{r}-3$.

in Table 7. The values given are pooled results of the replicate balance experiments. Total $\mathrm{N}$ excretion of pigs receiving diets containing DMC or WFM was similar. Urea- $\mathrm{N}$ and ammonia- $\mathrm{N}$ were the main components of this excretion. Pigs given DMC excreted more ammonia- $\mathrm{N}$ and allantoin- $\mathrm{N}$ but less urea- $\mathrm{N}$ than those given the WFM diet. Outputs of allantoin- $N$ were similar in pigs receiving the $P F$ and WFM diets. The excretion of $\mathrm{N}$ in the form of ammonia, urea, uric acid and allantoin accounted for $8 \mathrm{I}, 9 \mathrm{I}$ and $99 \%$ of the total $\mathrm{N}$ excreted by the groups given the PF diet, and the diets with DMC and WFM respectively. 


\section{J. P. F. D'Mello, D. G. Peers and C. T. Whittemore 1976}

Table 5. Metabolic faecal amino acids of growing pigs given the protein-free diet*

(Values for second replicate experiment only; mean values for four animals/diet)

$\begin{array}{lcc}\text { Amino acid } & \mathrm{g} / \mathrm{d} & \mathrm{g} / \mathrm{kg} \mathrm{DM} \text { in } \\ \text { Aspartic acid } & & \\ \text { Threonine } & 0.72 & 0.8 \mathrm{I} \\ \text { Serine } & 0.34 & 0.38 \\ \text { Glutamic acid } & 0.31 & 0.35 \\ \text { Glycine } & 0.68 & 0.77 \\ \text { Alanine } & 0.35 & 0.39 \\ \text { Valine } & 0.40 & 0.45 \\ \text { Cystine } & 0.35 & 0.39 \\ \text { Methionine } & 0.11 & 0.12 \\ \text { Isoleucine } & 0.12 & 0.14 \\ \text { Leucine } & 0.31 & 0.35 \\ \text { Tyrosine } & 0.45 & 0.51 \\ \text { Phenylalanine } & 0.28 & 0.32 \\ \text { Lysine } & 0.28 & 0.32 \\ \text { Histidine } & 0.43 & 0.48 \\ \text { Arginine } & 0.12 & 0.14 \\ & 0.31 & 0.35\end{array}$

DM, dry matter.

* For details, see Tables $1-3$.

Table 6. Digestibility of amino acids in diets containing methanol-grown, dried microbial cells $(D M C)$ and white fish meal (WFM) fed to growing pigs

(Values for second replicate experiment only; mean values for four animals/diet)

Digestibility

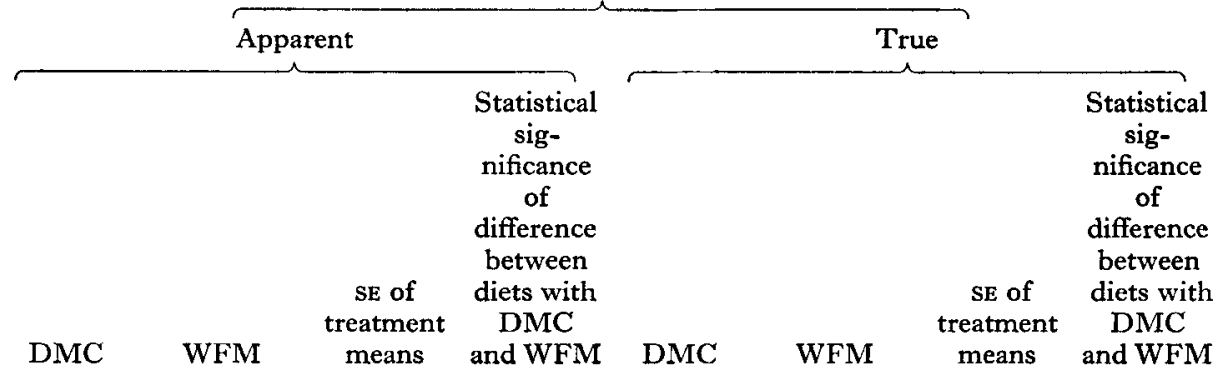

Amino acid

Threonine

$0.952 \quad 0.918$

$$
0.0096
$$

0.962

0.945

0.0062

0.0065

Serine

0.949

0.943

0.0050

0.0059

0.964

Glycine

0.958

Alanine

0.967

0.934

Valine

0.964

0.938

0.0062

0.0073

0.0095

Methionine

0.943

0.919

Isoleucine

0.956

0.949

0.0050

0.0081

$0.93 \mathrm{I}$

Leucine

0.955

0.931

Tyrosine 0.942

0.924

0.0086

0.0110

0.0094

0.924

Lysine 0.960

0.927

0.0083

Histidine

0.968

0.923

0.0058

$*$
NS
NS
$*$
NS
$* *$
$*$
NS
$*$
NS
NS
NS
NS
$*$
$* *$
NS

0.993
0.994
0.995
1.003
0.986
0.995
0.996
1.027
0.997
0.996
0.992
0.987
0.985
1.002
1.005
0.998

0.979

0.0096

0.991

0.983

0.0063

0.0064

0.984

$0.005 \circ$

0.987

0.979

0.980

0.965

0.985

0.986

0.980

0.985

0.973

0.988

0.977

0.0059

0.0065

0.0072

0.0097

0.0050

0.0083

0.0087

0.0111

0.0094

0.0087

0.0057

0.985

0.0064 
Table 7. Urinary excretion of total nitrogen, ammonia- $N$, urea- $N$, uric acid- $N$ and allantoin- $N(\mathrm{mg} / \mathrm{d})$ by growing pigs given the protein-free $(P F)$ diet or the diets containing methanol-grown, dried microbial cells $(D M C)$ or white fish meal (WFM)

\begin{tabular}{|c|c|c|c|c|c|c|c|c|c|c|}
\hline \multirow[b]{2}{*}{ Diet* } & \multicolumn{2}{|c|}{ Total N } & \multicolumn{2}{|c|}{ Ammonia-N } & \multicolumn{2}{|c|}{ Urea-N } & \multicolumn{2}{|c|}{ Uric acid-N } & \multicolumn{2}{|c|}{ Allantoin- $N$} \\
\hline & Mean & $\mathrm{SE}$ & Mean & $\mathrm{SE}$ & Mean & $\mathrm{SE}$ & Mean & SE & Mean & $\mathbf{S E}$ \\
\hline \multirow[t]{2}{*}{$\mathrm{PF}$} & 29 II & 70 & 1667 & 29 & 526 & 32 & $34 \cdot 6$ & $\mathbf{I} \cdot 7$ & I3I & 5 \\
\hline & & & \multicolumn{8}{|c|}{ Total 2359} \\
\hline \multirow[t]{2}{*}{ DMC } & I I I 70 & 305 & $276_{5}$ & 27 & 6854 & 2,18 & $68 \cdot 0$ & $I \cdot 6$ & 486 & I I \\
\hline & & & \multicolumn{8}{|c|}{ Total ror 73} \\
\hline \multirow[t]{2}{*}{ WFM } & 12846 & $3 \mathrm{II}$ & 2099 & 54 & 10424 & 368 & $56 \cdot 8$ & 0.7 & I 35 & 4 \\
\hline & & & \multicolumn{8}{|c|}{ Total 12715} \\
\hline
\end{tabular}

\section{DISCUSSION}

Estimates of metabolic faecal $N$ in the present study were $\mathrm{I} \cdot 20$ and $\mathrm{I} \cdot 3 \mathrm{I} \mathrm{g} / \mathrm{kg} \mathrm{DM}$ consumed, marginally higher than the directly determined values of between 0.76 and $\mathrm{I} \cdot \mathrm{I} \circ \mathrm{g} / \mathrm{kg} \mathrm{DM}$ intake summarized by Armstrong \& Mitchell (1955).

It is clear that the batches of DMC and WFM used in the present studies were of similar high digestibility, with values ranging from 0.91 to 0.98 . These findings for DMC are in contrast to those obtained by Oslage \& Schulz (1974) who recorded values for bacterial products of $0.8 \mathrm{r}$ for organic matter and 0.84 for crude protein digestibility, but much higher values for $n$-paraffin-grown yeast $(0.94$ and 0.93 respectively).

Amino acid digestibilities should be interpreted with caution owing to the modifying influence of microbial activity in the large intestine (Carpenter \& Booth, 1973; Holmes, Bayley \& Horney, 1974). Nevertheless, it would appear that methanolgrown DMC compares favourably in terms of amino acid digestibility with WFM (Table 6). Furthermore, the lysine digestibility values for DMC, ranging from 0.96 to $\mathrm{I} \cdot 00$, compare well with a fluorodinitrobenzene-availability value of $0.9 \mathrm{I}$.

Braude et al. (1975) indicated that $\mathrm{N}$ retention was not significantly different when pigs were offered cereal-based diets containing either DMC or WFM. Estimates given in Table 4 indicate lower retention and $\mathrm{BV}$ with the WFM diet than with the DMC diet, presumably a reflexion of the lower intakes of lysine and possibly threonine of pigs given the former diet (Table 3). It would appear that despite the higher nucleic acid-N content of DMC, the diet containing this product has an essential amino acid composition which compares favourably with that of the WFM diet. These values for net protein utilization and $\mathrm{BV}$ were obtained under conditions of moderate energy intake, and as such, are not strictly comparable with values obtained under the usual classical condition of a more generous energy allowance. 
However, the results obtained allow comparisons to be made of net protein utilization and BV between the diets containing WFM and DMC.

Although total urinary $\mathrm{N}$ excretion was similar in pigs given diets containing DMC or WFM, the proportions of individual nitrogenous components varied. The greater excretion of ammonia- $\mathrm{N}$ and allantoin- $\mathrm{N}$ by pigs given $\mathrm{DMC}$ presumably reflected breakdown of pyrimidine and purine moieties of nucleic acids. If it is assumed that the quantity of nitrogenous constituents in the urine of pigs given the $\mathrm{PF}$ diet reflects turnover and catabolism of cellular proteins and nucleic acids and that this remains constant, the proportion of excreted $\mathrm{N}$ derived from dietary sources may be calculated. The excretion of allantoin- $\mathrm{N}$ by pigs given the PF diet or the WFM diet was similar. This would appear to suggest that the additional $355 \mathrm{mg} \mathrm{N}$ recovered daily in the urine of pigs given DMC was derived from catabolism of the purine fraction of bacterial nucleic acids. The daily intake of nucleic acid- $\mathrm{N}$ from methanol-grown DMC was $642 \mathrm{mg}$. Assuming that digestion and catabolism of nucleic acid- $\mathrm{N}$ is complete, and that purine- $\mathrm{N}$ represents about $64 \%$ of this, a maximum of $4 \mathrm{II} \mathrm{mg}$ allantoin-N would have been expected. Since only $355 \mathrm{mg}$ was actually recovered, it is possible that $56 \mathrm{mg}$ purine- $\mathrm{N} / \mathrm{d}$ was salvaged. A similar calculation for pyrimidines is not feasible since the end-product of catabolism, ammonia, is common to many pathways.

Since the quantity of urinary $\mathrm{N}$ in the form of urea reflects the catabolism of dietary protein, the lower value recorded for pigs given DMC in comparison with those given WFM is consistent with the higher $\mathrm{BV}$ of the bacterial product.

The financial support of Imperial Chemical Industries Ltd, Agricultural Division, PO Box I, Billingham, Cleveland, is gratefully acknowledged. We are also indebted to Dr P. Crooks and the Central Analytical Laboratory of the Edinburgh School of Agriculture for chemical analyses, and to Mr A. G. Taylor and Mr I. Moffat for their technical assistance.

\section{REFERENCES}

Armstrong, D. G. \& Mitchell, H. H. (I955). F. Anim. Sci. x4, 49.

Braude, R., Mitchell, K. G. \& Rhodes, D. N. (1975). Proc. Nutr. Soc. 34, 5 IA.

Carpenter, K. J. \& Booth, V. H. (1973). Nutr. Abstr. Rev. 43, 423.

Crowley, L. V. (I964). Clin. Chem. 10, 838.

Holmes, J. H. G., Bayley, H. S. \& Horney, F. D. (1974). Br. F. Nutr. 32, 639.

Inglis, A. S. \& Leaver, I. H. (1964). Analyt. Biochem. 7, ro.

Marsh, W. H., Fingerhut, B. \& Miller, H. (1965). Clin. Chem. I1, 624.

Oslage, H. J. \& Schulz, E. (1974). Commission on Pig Production, 25th Meet. Eur. Ass. Anim. Prod., Copenhagen.

Pentz, E. I. (1970). Adv. autom. Analysis I, I I . 